University of Arkansas, Fayetteville

ScholarWorks@UARK

$1-24-2019$

\title{
Local Labor Market Conditions, Principals' Leadership, Conscientiousness, and Beginning Teacher Turnover: A Study During the Great Recession
}

\author{
Dillon Fuchsman \\ University of Arkansas, Fayetteville \\ Gema Zamarro \\ University of Arkansas, Fayetteville
}

Follow this and additional works at: https://scholarworks.uark.edu/edrepub

Part of the Educational Assessment, Evaluation, and Research Commons, Educational Leadership Commons, and the Other Educational Administration and Supervision Commons

\section{Citation}

Fuchsman, D., \& Zamarro, G. (2019). Local Labor Market Conditions, Principals' Leadership, Conscientiousness, and Beginning Teacher Turnover: A Study During the Great Recession. Education Reform Faculty and Graduate Students Publications. Retrieved from https://scholarworks.uark.edu/ edrepub/68

This Article is brought to you for free and open access by the Education Reform at ScholarWorks@UARK. It has been accepted for inclusion in Education Reform Faculty and Graduate Students Publications by an authorized administrator of ScholarWorks@UARK. For more information, please contact scholar@uark.edu. 


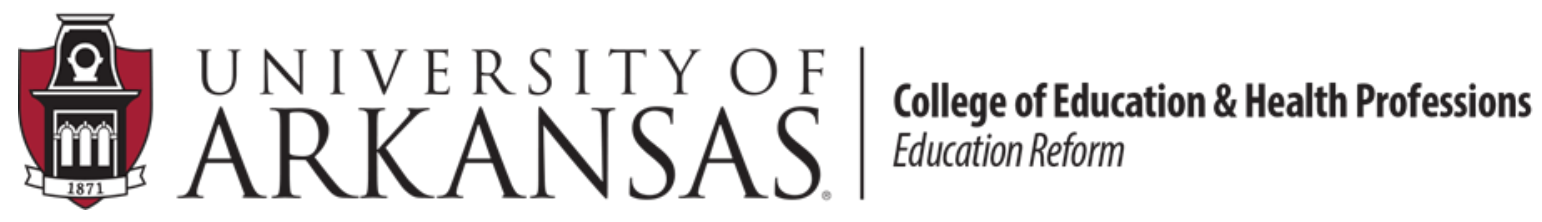

\title{
WORKING PAPER SERIES
}

\section{Local Labor Market Conditions, Principals' Leadership, Conscientiousness, and Beginning Teacher Turnover: A Study During the Great Recession}

\author{
Dillon Fuchsman \& Gema Zamarro
}

January 25, 2019

EDRE Working Paper 2019-01

The University of Arkansas, Department of Education Reform (EDRE) working paper series is intended to widely disseminate and make easily accessible the results of EDRE faculty and students' latest findings. The Working Papers in this series have not undergone peer review or been edited by the University of Arkansas. The working papers are widely available, to encourage discussion and input from the research community before publication in a formal, peer reviewed journal. Unless otherwise indicated, working papers can be cited without permission of the author so long as the source is clearly referred to as an EDRE working paper. 


\title{
char·asse $\cdot$ in
}

THE CHARACTER ASSESSMENT INITIATIVE

\section{Local Labor Market Conditions, Principals' Leadership,}

Conscientiousness, and Beginning Teacher Turnover: A Study During

\author{
the Great Recession
}

\section{Dillon Fuchsman*}

University of Arkansas

Gema Zamarro

University of Arkansas

January 2019

* Corresponding author. University of Arkansas. Address: 208 Graduate Education Building. College of Education and Health Professions Fayetteville, AR, USA 72701. Email: dsfuchsm@email.uark.edu. 


\begin{abstract}
An abundance of literature sheds light on which factors determine teacher turnover, but it has yet to consider the role that local labor market conditions may play in teachers' turnover decisions and how these labor market conditions may influence the quality of teachers who might be retained. The effect of local labor market conditions on teacher turnover could be relevant especially in times of high economic instability like the Great Recession. To study the determinants of teacher turnover, we match the Beginning Teacher Longitudinal Study (BTLS) with local unemployment rates from the USC Great Recession Indicators Database (GRID). We also build proxy measures of teachers' conscientiousness with levels of survey effort on the baseline BTLS survey. Our results show that, in the absence of changes in unemployment, teachers who present lower levels of conscientiousness, by means of lower effort in the baseline survey, also present lower probabilities of teacher turnover during their first years of teaching. However, higher conscientious teachers seem to be better retained when there is more instability in their local labor markets. Higher quality principals appear to help retain teachers, but they seem to be more effective at retaining those teachers who show lower levels of conscientiousness on their baseline survey.
\end{abstract}

Keywords: teacher turnover, Great Recession, non-cognitive skills, local labor markets JEL codes: I20, J83, C83 


\section{Introduction}

Voluntary teacher turnover is concerning for schools and students. Costly searches to replace teachers are a drain on school resources ${ }^{1}$ (Barnes et al, 2007; Birkeland \& Curtis, 2006; Milanowski \& Odden, 2007) and teacher turnover negatively affects students' achievement on standardized tests (Ronfeldt et al., 2013). The effect of teacher turnover compounds when considering that replacement teachers appear to be, on average, less effective (Rockoff, 2004; Harris \& Sass, 2011; Papay \& Kraft, 2015).

In response to the policy concerns posed by teacher turnover, there exists ample academic literature documenting the important role of principal quality (Boyd et al., 2009; Grissom, 2011; Kraft et al., 2016; Ladd, 2011) and teacher and student body characteristics (Allensworth et al., 2009; Boyd et al., 2011; Ladd, 2009 \& 2011; Borman \& Dowling, 2008; Johnson et al., 2012; Kraft et al., 2016; Loeb et al., 2005; Marinell and Coca, 2013) on teacher turnover decisions. However, this teacher turnover literature has yet to consider the role that local labor market conditions may play in teachers' turnover decisions and how they affect the levels of quality of teachers who might be retained.

In this paper, we utilize variation in teachers' local labor market conditions induced by the Great Recession to study teacher turnover during a time of great economic instability. The Great Recession began in December 2007 (National Bureau of Economic Research, 2008) and ended in June 2009 (NBER, 2010). Beginning teachers hired just prior to the Great Recession would make their first decision about exiting their schools in what would be an unusually volatile local labor market.

${ }^{1}$ These costs on school resources are those associated with separation, recruiting, hiring, and training new teachers. Milanowski and Odden (2007) show the only large benefit of teacher turnover would be in net replacement pay, since new teachers are lower on the salary schedule than where the exiting teacher is located on the salary schedule, but these gains are outweighed by other costs. 
An emerging literature highlights the potential role of local labor market conditions on teachers' hiring, retention and quality of the teachers labor force. Research based on teachers in California and Washington State shows that teachers voluntarily left their schools at higher rates during times of increased layoffs during the Great Recession, even beyond the required rate to compensate for budget shortfalls (Goldhaber et al., 2016). In Florida, teachers with higher contributions to their students' test scores (i.e. higher value-added teachers) were more likely to be hired during recessions but were also more likely to leave the profession years after ${ }^{2}$ (Nagler et al., 2015). More research, however, is needed to understand the determinants of voluntary teacher turnover when local labor markets are instable.

We are also interested in studying the levels of quality of teachers that might be retained by local labor market conditions. Specifically, we study a unique determinant of teacher turnover by following a developing literature that proposes that an individual's effort on surveys can capture meaningful non-cognitive skills related to conscientiousness (Hedengren \& Stratmann, 2012; Hitt, Trivitt, \& Cheng, 2016), that is diligence and desire to do a task well. Teacher's conscientiousness proxied by survey effort could unveil important dimensions of teacher quality not well captured by test score value-added teacher contributions (Cheng \& Zamarro, 2018). To our knowledge, only three other studies have looked at the role of conscientiousness in teacher turnover decisions finding either null effects or that conscientious teachers have lower teacher turnover rates (Bastian et al., 2017; Robertson-Kraft \& Duckworth, 2014; Rockoff, Jacob, Kane, \& Staiger, 2011). However, none of this previous work uses a national sample of teachers nor looks at how these effects could vary with local labor market shocks.

\footnotetext{
${ }^{2}$ Nagler et al.'s (2015) analysis considers recessionary hires for all recessions going back as far as 1970. Importantly, their teacher turnover analysis is only for teacher turnover decisions for the 2008-09 school year. As a result, teachers hired during the Great Recession would have been hired for the 2008-09 school year and are not included in their teacher turnover analysis.
} 
This paper focuses on the effects of the Great Recession on voluntary beginning teacher turnover. We explore the traditional determinants of teacher turnover as well as less studied factors like local labor market conditions and measures of teachers' conscientiousness proxied by survey effort. To do so, we merge data from the BTLS with unemployment data from the USC Great Recession Indicators Database (GRID).

Our results indicate that, in the absence of changes in unemployment, teachers with lower levels of conscientiousness, based on effort on the baseline BTLS survey, present lower probabilities of teacher turnover and are less likely to switch schools during their first years of teaching. This finding is in contrast to prior work that found that more conscientious teachers presented lower levels of turnover. We also find that higher conscientious teachers seem to be better retained in times of more instability in their local labor markets. Finally, as with prior literature, we find that higher quality principals help retain teachers in their current schools. However, they seem to be more effective at retaining those teachers who show lower levels of conscientiousness on their baseline surveys than those who exert more effort.

These results have important policy implications. To the extent that teacher survey effort captures meaningful dimensions of teacher quality (Cheng and Zamarro, 2018), our results suggest that we need better strategies to retain highly conscientious teachers. While principals are generally effective at improving teacher retention (Boyd et al., 2011; Grissom, 2011; Kraft et al., 2016; Ladd, 2011), they appear less effective at retaining conscientious teachers.

The rest of this paper is organized as follows. Section 2 provides background concerning teacher turnover broadly, the Great Recession, and conscientiousness. In section 3, we describe the data and specific measures that are part of our analysis. Section 4 describes our empirical approach to study the determinants of beginning teacher labor movements. In section 5, we 
present the results of our analysis. Finally, we conclude the paper with a discussion of the results and policy implications.

\section{Background}

A 2015 report by the National Center for Education Statistics pegs the annual rate of teacher turnover after the first year of a teacher's career at 10 percent and 17 percent within the first five years (Gray \& Taie, 2015) ${ }^{3}$. Considerable literature has aimed to shed light on which factors determine teacher turnover (see, e.g., Guarino et al., 2006; Borman \& Dowling, 2008). Several teacher characteristics are found to predict teacher turnover including demographic characteristics and type of certification (Boyd et al., 2006; Kane, Staiger, \& Rockoff, 2008). Student body characteristics also factor into teacher turnover decisions (Allensworth et al., 2009; Boyd et al., 2011; Ladd, 2009 \& 2011; Borman and Dowling, 2008; Loeb et al., 2005). Overall, organizational factors such as school leadership, school safety and discipline, academic expectations for students, teachers' collaboration and support appear to be stronger predictors of teacher turnover than individual teacher traits or average characteristics of students in the school (Allensworth et al., 2009; Boyd et al., 2011; Johnson et al., 2012; Kraft et al., 2016; Ladd, 2011; Loeb et al., 2005; Marinell and Coca, 2013).

Researchers have also looked at how teacher quality, measured by teacher's contributions to test scores through value-added models, relates to teacher turnover. Prior to the Great Recession, high quality teachers, on average, are found to be less likely to leave the teaching profession in Washington State (Krieg, 2006); Texas (Hanushek, Kain, O’Brien, \& Rivkin, 2005); New York City (Boyd et al., 2007); and North Carolina (Goldhaber, Gross, and Player, 2007). On average, teachers in Florida with high value-added tend to change schools less often,

\footnotetext{
${ }^{3}$ See appendix table 1 for a breakdown of the rate of beginning teacher turnover in the first five years of a teacher's career.
} 
but teachers at the high and low ends of the quality distribution tend to leave the profession more (Feng \& Sass, 2017). To our knowledge, Henry, Bastian, and Fortner (2011) are the only authors whose study includes data from the Great Recession. The authors find that the beginning teachers in the first five years of their career who left the classroom in North Carolina during this time were less effective on average.

One consistent finding in the literature is that principals' effectiveness and leadership reduce the likelihood of teacher turnover (Boyd et al., 2011; Grissom, 2011; Kraft et al., 2016; Ladd, 2011). Both Kraft et al. (2016) and Ladd (2011) include data of the Great Recession years, but they do not explicitly study the effect of local labor market conditions.

Grissom and Bartanen (2018) connect principal quality to retaining high quality teachers relative to low quality teachers, or "strategic teacher retention". Whereas previous work relied solely on teacher survey responses to measure principal quality, the authors combined teacher surveys with principal evaluations conducted by district leaders in Tennessee in their analysis. Their data covered post-Great Recession years from 2011-12 to 2016-17. They corroborate the previous finding that high quality principals can reduce the probability of teacher turnover. Additionally, they find that effective principals seem to be better at retaining high quality teachers based on classroom observations ${ }^{4}$ but not based on student growth or achievement.

\subsection{The Great Recession and Teacher Turnover}

The Great Recession decimated the American economy with peak unemployment reaching 10 percent and peak long-term unemployment ${ }^{5}$ reaching 4.4 percent in October 2009. Over 326,000 individuals filed for unemployment insurance from over 3,000 firms in February 2009 alone (Bureau of Labor Statistics, 2012). Educators were not immune to the effects of the

\footnotetext{
${ }^{4}$ Trained observers typically perform the classroom observations, but that observer is usually the principal.

${ }^{5}$ An individual unemployed for 27 continuous weeks is considered long-term unemployed.
} 
Great Recession; teacher layoffs totaled approximately 170,000 teachers during the Recession (National Education Association, 2010).

Research about the effects of the Great Recession on the teacher labor market have mostly focused on how different layoff structures during the Great Recession could have affected the distribution of teacher quality (Boyd et al., 2011; Kraft, 2015). Overall, this research found that layoffs were not very related to teacher quality measures based on value-added test score contributions or classroom observations. The authors argued more targeted layoffs based on value-added measures would have been more effective at improving student achievement rather than the general "last-in-first-out" ${ }^{6}$ " layoff structure. Similarly, Goldhaber and Theobald (2013) studied the predictors of layoffs in Washington State and found that seniority, possession of a master's degree, and subject area credentials predicted lower probabilities of layoffs while valued-added did not affect the probability of layoff. In Washington State and the Los Angeles Unified School District (LAUSD), teachers receiving notices of their impending layoff who are not actually laid off present lower levels of reading and math value-added than teachers who are never at risk of being laid off (Strunk et al., 2018).

A gap in the literature exists concerning the characteristics of teachers electing to voluntarily leave their school during the Great Recession. We could only identify two paper in the literature that did so. In Florida, higher value-added teachers hired during previous recessions were more likely to leave their school (Nagler et al., 2015). Using data from Los Angeles Unified School District and Washington State, Goldhaber et al. (2016) show that, relative to a teacher not receiving any layoff notice during the great recession, teachers receiving a layoff notice that do not end up being laid off had a higher probability of switching schools within the

\footnotetext{
${ }^{6}$ Last-in-first-out is a layoff structure that rewards individuals with longer tenure. The first people laid off are the last ones hired.
} 
district. Experienced teachers in LAUSD and inexperienced teachers in Washington State with rescinded layoff notices were more likely to switch schools within the district relative to teachers never receiving notices.

\subsection{Conscientiousness and Teacher Turnover}

In general, individuals' levels of conscientiousness appear to be an important determinant of job performance, retention, and job satisfaction (Barrick \& Mount, 1991; Barrick \& Zimmerman, 2009; Dalal, 2005; Hurtz \& Donovan, 2000; Roberts, Harms, Caspi, \& Moffitt, 2007). Importantly, among teachers, self-reported higher conscientiousness corresponds with lower levels of burnout and higher morale, which may affect turnover decisions (Kokkinos, 2007; Teven, 2007).

Only three prior studies have looked at the relationship between teacher conscientiousness and teacher turnover. Rockoff, Jacob, Kane, \& Staiger (2011) found that, among beginning teachers in New York City in the 2006-07 school year, conscientiousness did not predict teacher turnover the following year. Robertson-Kraft and Duckworth (2014) used a convenience sample of Teach for America beginning teachers from low-income districts and find that teachers with higher levels of grit, a non-cognitive skill associated with conscientiousness, are more likely to be retained throughout the first year than their less gritty counterparts ${ }^{7}$. Bastian et al. (2017) uses a sample of first year teachers in the 2013-14 academic year in North Carolina to study the effect of personality traits on teacher retention. The authors find that conscientious teachers have lower rates of attrition. It should be stressed, however, that none of these studies was able to study teacher turnover during the Great Recession.

\footnotetext{
${ }^{7}$ Robertson-Kraft and Duckworth (2014) examine a beginning cohort of Teach for America teachers whose first year in the classroom was the 2006-07 school year, which is prior to the Great Recession. The authors also only evaluate within-year teacher turnover decisions rather than between year teacher turnover decisions.
} 
In order to study the role of conscientiousness in teacher turnover decisions, we use a teacher's item non-response rate on their baseline BTLS survey as a proxy for their level of conscientiousness. Three recent studies have shown the potential of item non-response to proxy for relevant non-cognitive skills. Hedengren and Stratmann (2012), taking advantage of longitudinal nationally representative samples of adolescents and adults from Germany and the U.S., find item non-response to be correlated with self-reported measures of conscientiousness and a strong predictor of earnings and mortality risks later in life. Hitt, Trivitt, and Cheng (2016) wield six nationally representative, longitudinal datasets of American adolescents to show that the number of questions skipped on a paper and pencil survey was a significant predictor of educational attainment and labor outcomes later in life, even after controlling for cognitive ability. Lastly, Cheng and Zamarro (2018), using data from the Measures of Effective Teaching (MET) longitudinal database, found that teacher item non-response rates in a baseline survey captured important dimensions of teacher quality as they were found to be correlated with performance in classroom observation protocols and with student ratings of their teachers. Teacher survey effort measures were also found to be related to student cognitive and noncognitive skills like math test scores and student self-reported effort in class.

\section{Data}

We use the Beginning Teacher Longitudinal Study (BTLS), a five-year nationally representative panel dataset comprised of beginning teachers collected during the Great Recession. Data collection began with the Schools and Staffing Survey (SASS) in the 2007-08 school year (Wave 1) and the Teacher Follow-up Survey (TFS) in 2008-09 (Wave 2). BTLS extracted the subsample of first year teachers in public schools from SASS and continued to interview those beginning teachers for three more school years after the TFS (2009-10 through 
2011-12 school years, Waves 3 to 5). BTLS contains responses from almost 2,000 beginning teachers in the first year. These data are unique in that the BTLS continued to collect data for former teachers.

The 2007-08 iteration of SASS contained five questionnaires collecting information about the school district, the school, the principal, the teacher, and the library media center. It is possible to match information of these five questionnaires through a unique school identifier. Since the BTLS started as a subsample of SASS, we are able to match the first year teachers in BTLS to the information collected through the other four questionnaires. In particular, we utilize information collected in the school, principal, and teacher surveys.

Our analyses focus on full-time teachers in regular public schools, which excludes teachers in charter schools as charter school principals have more discretion in the recruitment and firing policies of their teachers ${ }^{8}$. We also only look at teachers who moved out of their original schools voluntarily ${ }^{9}$. With these restrictions in place, and excluding incomplete records, our analytical sample size starts at about 1,300 teachers.

\subsection{Measures of Teacher Turnover}

We categorize teachers in a given year into three groups: stayers, school changers, and leavers. Stayers are teachers who remain in the same school they taught in during wave 1. Changers are those who switch schools but continue to teach at some point during waves 2 through 5. Leavers are teachers who attrite from the teaching profession anytime during waves 2 through 5. For our analysis, we follow the convention in the literature of grouping school changers and leavers in the same category, henceforth movers. The intuition behind the mover

\footnotetext{
${ }^{8}$ Only about 4 percent of teachers in our sample work in a charter school.

${ }^{9}$ Since this data is based on a survey, teachers had to self-report that their contracts had not been renewed. About 3.2 percent of teachers self-reported they were terminated. About 0.2 percent of teachers reported their contract was not renewed due to a reduction in force.
} 
category is that the costs for schools to fill a vacancy are the same regardless of whether a teacher changes schools or quits teaching altogether; the school is out one teacher and may feel the need to fill the now vacant position. We also separate changers and leavers from the mover group as part of our analysis to determine different effects on these two types of teacher movements.

Figure 1 shows rates of teacher turnover based on the leaver-changer definition. Calculations of teacher turnover type are made based on the surviving population who remained in their original school in a given year. After the first year of teaching in our sample, about 20 percent of teachers move out of their original schools. The mover rate fell to 10 percent in wave 3 , increased slightly to 12 percent in wave 4 , and fell to 8 percent in wave 5 . Except for wave 4, the percentage of leavers was about half the percentage of changers. The proportions of leavers and changers fell from wave 2 to wave 3, rose prior to wave 4 , and fell again prior to wave 5 . The proportion of leavers and changers were highest in wave 2 at approximately 6 and 13 percent, respectively. The lowest proportion of leavers and changers were for wave 5 with 3 percent leavers and 5 percent changers.

\subsection{Survey Effort Measure as a Proxy Measure for Teacher Conscientiousness}

We follow the work of Hitt, Trivitt, and Cheng (2016) and build a proxy measure for teacher conscientiousness based on a beginning teacher's item non-response rate on the BTLS baseline survey (wave 1). This measure is built by dividing the total number of questions a teacher leaves blank by the number of answerable questions to which a teacher should have responded, given legitimate skips. The wave 1 survey was a long paper and pencil survey where teachers were asked to complete up to 339 questions. On average, respondents were asked to 
answer approximately 205 questions. For ease of interpretation, in our empirical analysis we standardize this measure to have mean zero and standard deviation one.

Figure 2 depicts the average item non-response for the baseline survey for all teachers in their original schools for each wave of the BTLS. The item non-response rate for the survivor population of teachers who remain in their original school in a given year ranges from 1.8 to 2 percent in our sample. Due to teacher turnover, the sample appears more conscientious in between waves 1 and 2 since the average item non-response rate falls between these waves. The average item non-response rates then increases each year after wave 2 suggesting that the more conscientious teachers left our sample, that is had lower rates of non-response in the survey.

\subsection{Measures of Principal Effectiveness and Other Determinants of Teacher Turnover}

We follow previous literature and construct a measure of principal effectiveness using factor analysis (see, Boyd et al., 2011; Grissom, 2011; Loeb, et al. 2005; Kraft et al., 2016). We use responses to five questions on the baseline wave 1 survey concerning principals' administrative support, rules enforcement, principals' communication, staff recognition, and satisfaction towards the school. We use responses from all teachers in the school, not only beginning teachers, answering the questionnaire for a given principal. Using all teachers in the school increases the amount of information available to capture principal quality and limits bias in principal evaluations by those teachers who already decided to leave the profession or change schools. We then construct an index of principal effectiveness by combining teachers' principal evaluations using a principal components analysis with a varimax (orthogonal) rotation. We retain a unique factor which presented an eigenvalue larger than one. All variables contribute almost equally to this factor based on their similar factor loadings. We average the principal effectiveness values predicted from our factor analysis for all teachers in the same school. We 
assign these overall average values of principal effectiveness to each BTLS teacher in that same school to use as her principal's effectiveness levels in the analysis of beginning teachers' turnover. The principal effectiveness variable is then standardized to have mean zero and standard deviation to easy interpretation in our analysis. Appendix 2 contains the questions that are part of the principal's effectiveness index and the factor loadings derived from this analysis.

In addition to the principal's effectiveness measure, our empirical models also include information derived from the baseline teacher survey on a teacher's gender, race/ethnicity, type of certification, educational attainment, whether the teacher had passed the Praxis test in reading, math, and writing, and whether the teacher had a mentor in the school as control variables in our analysis. Using the baseline school survey from SASS, we constructed variables for school characteristics such as proportion of students who are African American, Hispanic, and those who are eligible free and reduced-price lunch (FRL), as well as school enrollment, school type (elementary, middle, high, and combined ${ }^{10}$ ), magnet school status, and level of urbanicity in the school location. Finally, we used baseline SASS principal surveys to obtain information on a principal's gender, race/ethnicity, experience, and experience as a teacher.

Praxis tests are widely used tests that attempt to measure what potential teachers know about their content area as well as general teaching skills. Several states require passing these tests before a teacher may obtain a license. We use indicator variables for a teacher passing the Praxis test for reading, math, or writing as a proxy for a teacher's cognitive ability. However, not all states require teachers to pass Praxis exams for certification but our analysis includes region fixed effects which would partially take this into account.

\subsection{Local Labor Market Variables}

\footnotetext{
${ }^{10}$ Combined schools are those that serve students in grades that cross over what would traditionally be considered elementary, middle, or high schools.
} 
To measure the effects of local labor market conditions, we use the University of Southern California's Great Recession Indicators Database (GRID). Researchers at the USC Dornsife Center for Economic Research collected this detailed dataset containing labor market indicators either monthly or yearly at the county level. It contains information about local labor markets, hours of work, business patterns, the American Recovery and Reinvestment Act, and housing markets. In this paper we use county level unemployment rates. Since teachers must make a decision regarding whether or not to return to their original school during the school year, we used lagged average unemployment rates corresponding to each wave.

Figure 3 plots histograms for the county level unemployment rates. The vertical line in each histogram represents the average unemployment rate in 2006, pre-Great Recession. The distributions for the year 2006, pre-data collection, and the first year of data collection, 2007, look somewhat similar. However, when teachers make their first decision about whether or not to remain in their original school for wave 2, the distribution of county level unemployment rates starts to look different from the pre-Great Recession distribution. The waves 3 through 5 distributions look even less like the pre-Great Recession distributions. In each of the bottom four histograms corresponding to data waves 2 to 5 , the vast majority of data lie to the right of the vertical line indicating that the vast majority of counties experienced unemployment greater than the pre-Great Recession average. It should be emphasized that we observe considerable variance in unemployment rates across counties for each wave in our data.

We average county level unemployment rates for each school year and then build a measure of unemployment shocks by differencing the county-level average unemployment rate for a school year relative to the county-level average unemployment rate in the 2005-06 school year, before the Great Recession started. Our measure captures the percentage point change in 
the unemployment rate relative to when the national economy was seemingly stable. Figure 4 displays the distributions of changes in county level unemployment rates relative to 2006. It is important to note that although the Great Recession affected the whole country there is considerable variation on how much specific counties were affected and when. Initially, in 2007, changes were centered on zero with a smaller variance across counties. By 2008, the distribution of unemployment shocks had widened, but was still centered on zero. Each subsequent year has county-level changes to the unemployment rate that are dramatically shifted and present significantly higher variation across counties.

\section{Empirical Strategy}

We use a variety of duration models to study the determinants of teacher turnover. First, we study the dynamics of teacher turnover decisions wave by wave using discrete choice duration models with the following specification:

$\operatorname{Pr}\left(\right.$ Mover $\left._{i, w}=1 \mid X\right)=\Lambda\left(\beta_{0}+\beta_{1}\right.$ LocalLabor $_{i, w}+\beta_{2} I N R_{i, 1}+\beta_{3} P Q_{i, 1}+\beta_{4} T_{i, 1}+\beta_{5} S_{i, 1}+$ $\left.\beta_{6} P_{i, 1}\right)$

$w=2,3,4,5$

The models estimated in (1) predict the probability that teacher $i$ 's employment spell, in a given school, ends at wave $w$ conditional on the teacher surviving up to that wave. Since we are interested in the determinants of why a teaching spell in a school would end, we consider all teachers whose spells in the profession have not ended, either because of leaving the profession or changing schools, prior to a given wave. That is, we limit our empirical sample in a given wave to those teachers who have not left the profession or change schools. As updated characteristics of schools are not available to us for those teachers changing schools, teachers who leave their original school but not the profession only contribute once to the analysis 
sample. In the model described above, $\Lambda()$ denotes the cumulative logistic distribution function. Mover $_{i, w}$ is a dummy variable that takes value 1 if a teacher moves out of her original school in a wave. LocalLabor $r_{i, w}$ is the shock to a teacher's local labor market measured as the change in unemployment rates as described in section 3.4 above. $I N R_{i, 1}$ is the teacher's standardized item non-response rate measured on the baseline survey during wave one. $P Q_{i, 1}$ represents our measure of a principal's quality for the teacher's principal at baseline. $T_{i, 1}$ includes teacher characteristics measured at baseline wave 1: gender, ethnicity, if teacher is alternatively certified, if teacher has greater than or equal to a Master's degree, and if the teacher has passed the Praxis exam in math, reading, or writing, as a proxy measure for teacher's cognitive ability. $S_{i, 1}$ includes school demographics and characteristics measured at baseline wave 1: ethnic composition of school, proportion of students eligible for free or reduced price lunch, enrollment, and school urbanicity. $P_{i, 1}$ includes characteristics of a teacher's principal at baseline: gender, ethnicity, experience, and experience teaching. We also include region fixed effects to account for any remaining geographic unobserved factors.

Our second set of analysis uses competing-risk discrete choice duration models with a multinomial logit specification, analogous to the model in (1), but allowing for separate effects for the decisions of changing schools or leaving the profession altogether.

\section{Results}

\subsection{Descriptive Statistics}

Table 1 presents the descriptive statistics for our entire sample of beginning teachers as well as dividing the sample into teachers who ever moved from their original school during waves 2 to 5 and those who stayed in the same school for all five years. Panel A provides the descriptive statistics for teacher characteristics. On average, teachers left 2 percent of questions 
blank, but this rate was quite variable across teachers with a standard deviation of 4 percentage points ${ }^{11}$. On average, we find there was not a statistically significant difference in item nonresponse rates between teachers who ever left their original schools and those who stayed in their original schools all five years. Three-fourths of teachers in the sample were female and nine out of ten were white. Just over a quarter of teachers were alternatively certified ${ }^{12}$ and 16 percent had completed some graduate coursework. Less than half of teachers had passed their Praxis tests in reading, math, or writing. Nearly 90 percent of teachers had a mentor and teachers stayed just over two years in a school, on average. Movers were statistically significantly more likely to be alternatively certified and had fewer years of experience in a school.

Panel B displays the summary statistics for school characteristics. Teachers were in schools with, on average, 18 percent black students, 21 percent Hispanic students, and 45 percent free and reduced price lunch eligible students. Teachers left schools with lower proportions of black and FRL students at a statistically significantly lower rate. Average enrollment was 822 students. Elementary schools were 47 percent of the sample, middle schools were 18 percent, 29 percent were high schools, and the rest were schools that combined grades. Eight percent of the sample were magnet schools. Finally, suburban schools comprised almost 30 percent of schools, towns made up 16 percent, rural schools were 3 percent, and the remaining 24 percent were city schools.

Panel C contains the descriptive statistics for principal variables. Teachers who move out of their original schools leave behind more effective principals than the teachers who stay. Female principals made up about half of the sample, while black and Hispanic principals made

\footnotetext{
${ }^{11}$ We standardize item non-response in our multivariate analyses

12 The BTLS survey does not ask about which alternative certification program a teacher entered the classroom through.
} 
up only 11 percent and 8 percent of the sample, respectively. Principals had an average of 12 years of experience as principals, but only 0.23 years of experience as a teacher.

\subsection{Determinants of Teacher Turnover}

In tables 2 through 5, odd numbered columns present results for the specification in equation (1). Even columns include interaction terms for changes in the county unemployment rate and item non-response as well as interactions for item non-response and principal's quality. These interaction terms aim to capture any differential effects of local labor market conditions and principal quality depending on teachers' conscientiousness levels. All tables present average marginal effects.

We begin by discussing results from our discrete duration models (table 2). In the absence of changes in unemployment, on average, teachers who present higher levels of item non-response on the baseline survey present a lower likelihood of teacher turnover during the year immediately after their first year of teaching. A one standard deviation increase in item nonresponse corresponds with a four percentage points reduction in the probability of teachers leaving their original schools. However, we find that increases in local unemployment lead to decreases in the probability of teacher turnover for this year and that these effects were higher for teachers who presented higher effort on their baseline survey. Increasing county level unemployment rate by one percentage point was associated with a two percentage point reduction in the probability of teacher turnover immediately after the first year of teaching for those teachers with equivalent item non-response. Finally, as with prior literature, we find that higher quality principals help retain teachers in their current schools. In our full specification with interaction terms, increasing a principal's quality one standard deviation resulted in a 
reduction in the probability of teacher turnover by almost three percentage points for teachers with the same level of item non-response.

For the second year of teaching, we find no evidence that higher quality principals were able to retain high or low conscientiousness teachers differentially. However, this is different for the third and fifth year of teaching. In these later years, higher quality principals appear to be more successful at retaining teachers who present lower levels of conscientiousness by leaving more items blank on their baseline survey.

During the fourth year of their teaching careers, however, higher levels of unemployment lead to higher probabilities that a teacher leaves her original school, more so for less conscientious teachers. For teachers with comparable item non-response, a one percentage point increase in the local unemployment rate relative to 2006 led to a 1.5 percentage point increase in the probability of teacher turnover. However, a teacher who exhibited one standard deviation higher item non-response than a comparison teacher would have a 2.2 percentage point higher probability of moving out of the original school. Teachers with a one standard deviation higher quality principal had their probability of teacher turnover reduced by almost four percentage points.

Tables 3 through 5 are analogous to 2 except these tables present the average marginal effects from a competing-risk discrete duration model using a multinomial logit specification to allow the effects of our explanatory variables in the probability of staying, leaving, and changing schools to differ. Table 3 includes the effects for the probability of staying. The effects echo results from the discrete choice duration models in table 2 where the point estimates and statistical significance are nearly the same. After the first year, the probability of staying in the original school is predicted by increases in item non-response, changes in the local 
unemployment rate, and principal's quality. Between the third and fourth waves, increases in the probability of staying in the same school correspond with reductions in county level unemployment relative to 2006, increases in item non-response, and increases in principal quality. Staying in the original school between years 2 and 3 and between years 4 and 5 is not significantly predicted by most of our explanatory variables, with the exception being the interaction between principal quality and item non-response. The effects of item non-response and principal quality were largest in magnitude for year 4.

Dynamic determinants of the probability of leaving the profession are available in table 4. Most effects are insignificant except between years 3 and 4, where positive increases in unemployment relative to 2006 seem to increase the likelihood of a teaching leaving the profession, while higher quality principals and higher levels of item non-response decrease the probability of leaving. Leaving prior to the third year of a teacher's career correlates with higher item non-response and higher principal quality.

Finally, table 5 contains dynamic determinants of the probability of changing schools. Principal quality and item non-response are the only variables that significantly predict the likelihood of changing schools in more than one year. Between years 1 and 2 as well as 3 and 4, item non-response correlates with lower probabilities of changing schools. Principal quality predicts lower levels of school changing prior to years 3 and 4 . The interaction term between item non-response and principal quality is significant prior to years 3 and 5; teachers that are less conscientious and in schools with high quality principals are less likely to switch schools.

\section{Conclusion}

Teacher turnover is an important policy concern, given its adverse consequences for student achievement and the large financial costs imposed on schools. Teacher turnover is 
especially problematic among beginning teachers. While a breadth of literature has studied the determinants of teacher turnover, we expand by evaluating how local shocks to unemployment, teachers' levels of conscientiousness, and principal's quality all affect the likelihood of teacher turnover.

We use the national Beginning Teacher Longitudinal Study and the Great Recession Indicators Database to study the determinants of teacher turnover. We measure local labor market conditions using the difference between the county unemployment rates in a school year relative to the pre-Great Recession 2006 school year. We proxy for teacher's non-cognitive skills with a measure of survey effort: baseline survey item non-response. We rely on previous literature which showed that item non-response can be a valid proxy measure for non-cognitive skills related to conscientiousness (Hitt, Trivitt, \& Cheng, 2016) and that teachers' item nonresponse rates may capture important teacher quality dimensions missed by value-added test score based measures (Cheng \& Zamarro, 2018).

We observe that increases in local unemployment rates due to the Great Recession were associated with lower rates of teacher turnover immediately after the first year of teaching and that teachers presenting higher levels of conscientiousness through their effort in their baseline survey were more likely to exit their schools. Between the third and fourth years of a teacher's career, we find that a higher local unemployment rate relative to the 2006 school year increases the probability of teacher turnover; this effect is smaller, but still positive, for conscientious teachers. We corroborate the important role principals can play in reducing the probability of teacher exits but show that principals might be less effective at retaining teachers with higher levels of conscientiousness. 
Our results have two important implications for policy. First, these results suggest the need for better strategies to retain high conscientious teachers. To the extent our survey effort measures capture teacher's conscientiousness (Hedengren \& Stratmann, 2011; Hitt, Trivitt, \& Cheng, 2016) and meaningful dimensions of teacher quality (Cheng \& Zamarro, 2018), our finding that teachers with lower item non-response rates were more likely to exit their schools implies that districts policymakers could do more to retain more conscientious teachers. However, the negative effect of conscientiousness on teacher turnover was smaller for teachers in counties with large deviations in the unemployment rate from 2006. This finding suggests that conscientious teachers may stay in their schools more when there is greater economic instability.

Second, current efforts by principals may not be completely successful at retaining more conscientious teachers. Grissom and Bartanen (2018) found that high quality principals strategically retain high quality teachers when teacher quality is measured with principal's classroom observations. We find that high quality principals seem to be more effectively retaining teachers that are lower quality using conscientiousness as our measure of teacher quality.

Our results are limited since the BTLS survey does not contain any direct measure of conscientiousness and our proxy measure, item non-response, is a noisy measure that could be capturing other unobserved factors along with teacher's conscientiousness. More research is needed to fully understand the role of teacher's conscientiousness on turnover decisions but our paper provides evidence that local labor market conditions and principal quality could have a role on the quality of teachers who get to be retained. 


\section{References}

Allensworth, E., Ponisciak, S., \& Mazzeo, C. (2009). The School Teachers Leave: Teacher Mobility in Chicago Public Schools. Chicago, IL: Consortium on Chicago School Research, University of Chicago.

Barnes, G., Crowe, E., \& Schaefer, B. (2007). The Cost of Teacher Turnover in Five School Districts: A Pilot Study. Washington, DC: National Commission on Teaching and America's Future.

Barrick, M.R., \& Mount, M.K. (1991). The Big Five personality dimensions and job performance: A meta-analysis. Personnel Psychology, 4(1), 1-26

Barrick M. R., Zimmerman, R. D. (2009). Hiring for Retention and Performance. Human Resource Management, 48(2), 183-206.

Bastian, K. C., McCord, D. M., Marks, J. T., \& Carpenter, D. (2017). A temperament for teaching? Associations between personality traits and beginning teacher performance and retention. AERA Open, 3(1), 1-17.

Birkeland, S. E., \& Curtis, R. (2006). Ensuring the support and development of new teachers in the Boston Public Schools: A proposal to improve teacher quality and retention. Boston: Boston Public Schools.

Borman, G. D., Dowling, N. M. (2008). Teacher Attrition and Retention: A Meta-Analytic and Narrative Review of the Research. Review of Educational Research, 78(3), 367-409.

Boyd, D., Grossman, P., Ing, M., Lankford, H., Loeb, S., \& Wyckoff, J. (2011). The Influence of School Administrators on Teacher Retention Decisions. American Educational Research Journal, 48(2), 303-333.

Boyd, D., Grossman, P., Lankford, H., Loeb, S., Michelli, N., \& Wyckoff, J. (2006). Complex by design: Investigating pathways into teaching in New York City schools. Journal of Teacher Education, 57(2), 155-166.

Boyd, D., Lankford, H., Loeb, S., \& Wyckoff, J. (2011). Teacher layoffs: An empirical illustration of seniority versus measures of effectiveness. Education Finance and Policy, 6(3). 439-454.

Boyd, D., Grossman, P., Lankford, H., Loeb, S., \& Wyckoff, J. (2007). Who leaves? Teacher attrition and student achievement. Retrieved from https://cepa.stanford.edu/content/wholeaves-teacher-attrition-and-student-achievement

Bureau of Labor Statistics (2012). BLS spotlight on statistics: The Recession of 2007-2009. Retrieved from: https://www.bls.gov/spotlight/2012/recession/pdf/recession_bls_spotlight.pdf

Cheng, A. \& Zamarro, G. (forthcoming). Measuring teacher conscientiousness and its impact on students: Insight from the Measures of Effective Teaching longitudinal database (EDRE Working Paper 2016-05). Fayetteville, AR: Department of Education Reform, University of Arkansas. 
Dalal, R.S. (2005). A meta-analysis of the relationship between organizational citizenship behavior and counterproductive work behavior. Journal of Applied Psychology, 90(6). 1241-1255.

Feng, L. \& Sass, T. R. (2017). Teacher quality and teacher mobility. Education Finance and Policy, 12(3). 396-418.

Goldhaber, D. \& Theobald, R. (2013). Managing the teacher workforce in austere times: The determinants and implications of teacher layoffs. Education Finance and Policy, 8(4). 494-527.

Goldhaber D., Strunk, K. O., Brown, N. \& Knight, D. S. (2016). Lessons learned from the Great Recession: Layoffs and the RIF-induced teacher shuffle. Educational Evaluation and Policy Analysis, 38(3). 517-548.

Goldhaber, D., Gross, B., \& Player, D. (2007). Are public schools really losing their best? Assessing the teachers and their implication for the quality of the teacher workforce (CALDER Working Paper No 12). Washington, D.C.: CALDER.

Gray, L. \& Taie, S. (2015). Public school teacher attrition and mobility in the first five years: Results from the first through fifth waves of the 2007-08 Beginning Teacher Longitudinal Study (NCES 2015-337). Washington, D.C.: National Center for Education Statistics, Institute of Education Sciences, Department of Education.

Grissom, J. (2011). Can Good Principals Keep Teachers in Disadvantaged Schools? Linking Principal Effectiveness to Teacher Satisfaction and Turnover in Hard-to-Staff Environments. Teachers College Record, 113(11). 2552-2585.

Guarino C., Santibañez, L., \& Daley, G. A. (2006). Teacher Recruitment and Retention: A Review of the Recent Empirical Literature. Review of Educational Research, 76(2), 173208.

Hanushek, E. A., Kain, J. F., O'Brien, D. M., \& Rivkin, S. G. (2005). The market for teacher quality (NBER Working Paper No. 11154). Cambridge, MA: NBER

Harris, D. N. \& Sass, T. R., (2011). Teacher training, teacher quality and student achievement. Journal of Public Economics, 95(7-8), 798-812.

Hedengren, D. \& Stratmann, T. (2012). The dog that didn't bark: What item nonresponse shows about cognitive and non-cognitive ability. Working paper. Retrieved from https://papers.ssrn.com/sol3/papers2.cfm?abstract_id=2194373

Henry, G. T., Bastian, K. C., \& Fortner, C. K. (2011). Stayers and leavers: Early-career teacher effectiveness and attrition. Educational Researcher, 40(6). 271-280.

Hitt, C., Trivitt, J., \& Cheng, A. (2016). When you say nothing at all: The predictive power of student effort on surveys. Economics of Education Review, 52, 105-119.

Hurtz, G.M., \& Donovan, J.J. (2000). Personality and job performance: The Big Five Revisited. Journal of Applied Pscyhology, 85(6), 869-879. 
Johnson, S. M., Kraft, M. A., \& Papay, J. P. (2012). How context matters in high-need schools: The effects of teachers' working conditions on their professional satisfaction and their students' achievement. Teachers College Record, 114(10), 1-39.

Kane, T. J., Rockoff, J. E., \&Staiger, D. O. (2008). What does certification tell us about teacher effectiveness? Evidence from New York City. Economics of Education Review, 27(6), 615-631.

Kokkinos, C. (2007). Job stressors, personality and burnout in primary school teachers. British Journal of Educational Psychology, 77, 229-243.

Kraft M. A., Marinell, W. H., Yee, D. S. (2016). School Organizational Contexts, Teacher Turnover, and Student Achievement: Evidence From Panel Data. American Educational Research Journal, 53(5), 1411-1449.

Kreig, J. M. (2006). Teacher quality and attrition. Economics of Education Review, 25(1). 13-27.

Ladd, H. (2009). Teachers' perceptions of their working conditions: How predictive of policyrelevant outcome? (CALDER Working Paper No. 33). Washington DC: CALDER.

Ladd, H. (2011). Teachers' Perceptions of Their Working Conditions: How Predictive of Planned and Actual Teacher Movement? Educational Evaluation and Policy Analysis, 33(2), 235-261.

Loeb, S., Darling-Hammond, L., \& Luczak, J. (2005). How Teaching Conditions Predict Teacher Turnover in California Schools. Peabody Journal of Education, 80(3), 44-70.

Marcus, B. \& Schültz, A. (2009). Who are the people reluctant to participate in research? Personality correlates of four different types of nonresponse as inferred from self- and observer ratings. Journal of Personality, 73(4), 959-984.

Marinell, W. H., Coca, V. M. (2013). Who stays and who leaves? Findings from a three-part study of teacher turnover in NYC middle schools. New York, NY: Research Alliance for New York Schools.

Milanowski, A. T., \& Odden, A. R. (2007). A new approach to the cost of teacher turnover. Washington, DC: School Finance Redesign Project, Center on Reinventing Public Education.

Business Cycle Dating Committee, National Bureau of Economic Research (2008).

Determination of the December 2007 peak in economic activity. Retrieved from: http://www.nber.org/cycles/dec2008.html

Business Cycle Dating Committee, National Bureau of Economic Research (2010). Retrieved from: http://www.nber.org/cycles/sept2010.html

National Education Association (2010). Projected Educator Layoffs. Retrieved from: http://educationvotes.nea.org/wpcontent/uploads/2010/05/Chart_Layoff_Numbers_by_state_05_11.pdf 
Papay, J. P., \& Kraft, M. A. (2015). Productivity returns to experience in the teacher labor market: Methodological challenges and new evidence on long-term career improvement. Journal of Public Economics, 130, 105-119.

Roberts, B.W., Harms, P.D., Caspi, A., \& Moffitt, T.E. (2007). Predicting the counterproductive employee in a child-to-adult prospective study. Journal of Applied Psychology, 92(5), 1427-1436.

Robertson-Kraft, C., Duckworth, A. L. (2014). True Grit: Trait-Level Perseverance and Passion for Long-Term Goals Predict Effectiveness and Retention Among Novice Teachers. Teachers College Record, 116, 1-27.

Rockoff, J. (2004). The impact of individual teachers on student achievement: Evidence from panel data. American Economic Review, 94(2), 247-252.

Ronfeldt M., Loeb, S., \& Wyckoff, J. (2013). How Teacher Turnover Harms Student Achievement. American Educational Research Journal, 50(1), 4-36.

Shores, K. \& Steinberg, M. P. (2017). The impact of the Great Recession on student achievement: Evidence from Population Data. SSRN Working Paper. Retrieved from: https://papers.ssrn.com/sol3/papers.cfm?abstract_id=3026151

Teven, J. J. (2007). Teacher Temperament: Correlates with Teacher Caring, and Organizational Outcomes. Communication Education, 56(3), 384-400. 


\section{Figures}

Figure 1: Proportions of Teachers who Change Schools or Leave the Profession by Wave

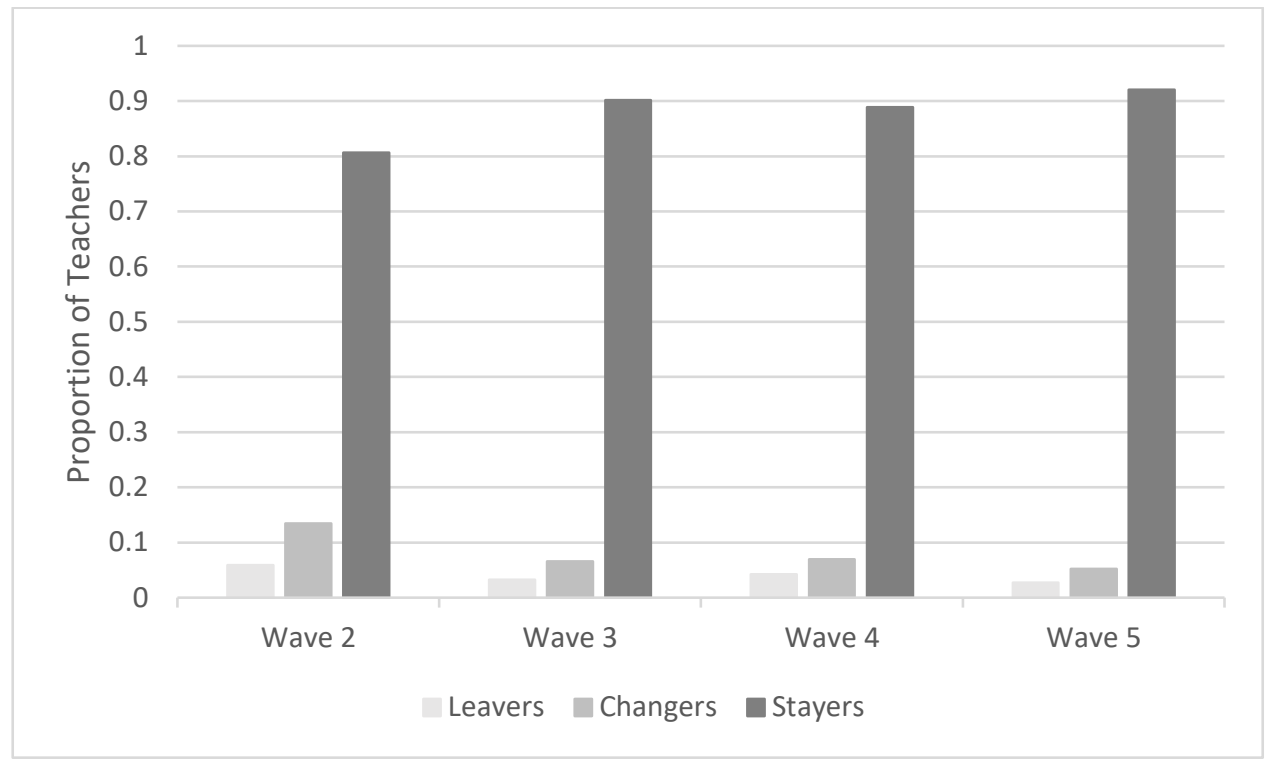

Note: Calculations of teacher turnover type are made based on the surviving sample who remained in their original school a given year. Approximately 1,300 teachers in wave 2, 1,100 in wave 3, 920 in wave 4 and 760 in wave 5 . Wave 2 is the 2008-09 school year, wave 3 is the 2009-10 school year, wave 4 is the 2010-11 school year, and wave 5 is the 2011-12 school year. Provided calculations using sampling weights. 
Figure 2: Average Item Non-Response based on Surviving Teacher

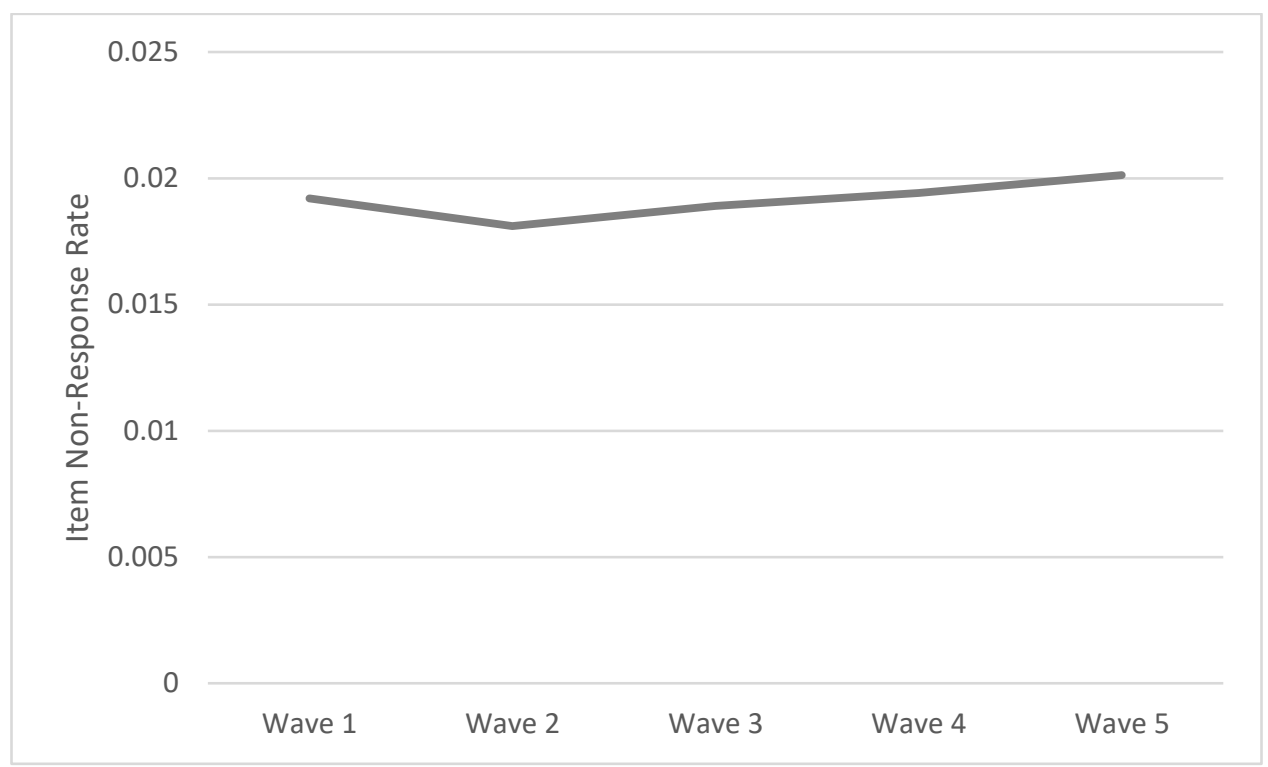

Note: Approximately 1,300 teachers in waves 1 and 2, 1,100 in wave 3,920 in wave 4 and 760 in wave 5 . Wave 1 is the 2007-08 school year, wave 2 is the 2008-09 school year, wave 3 is the 2009-10 school year, wave 4 is the 201011 school year, and wave 5 is the 2011-12 school year. Provided calculations using sampling weights. 
Figure 3: Distribution of County Level Unemployment Rates from School Year to School Year
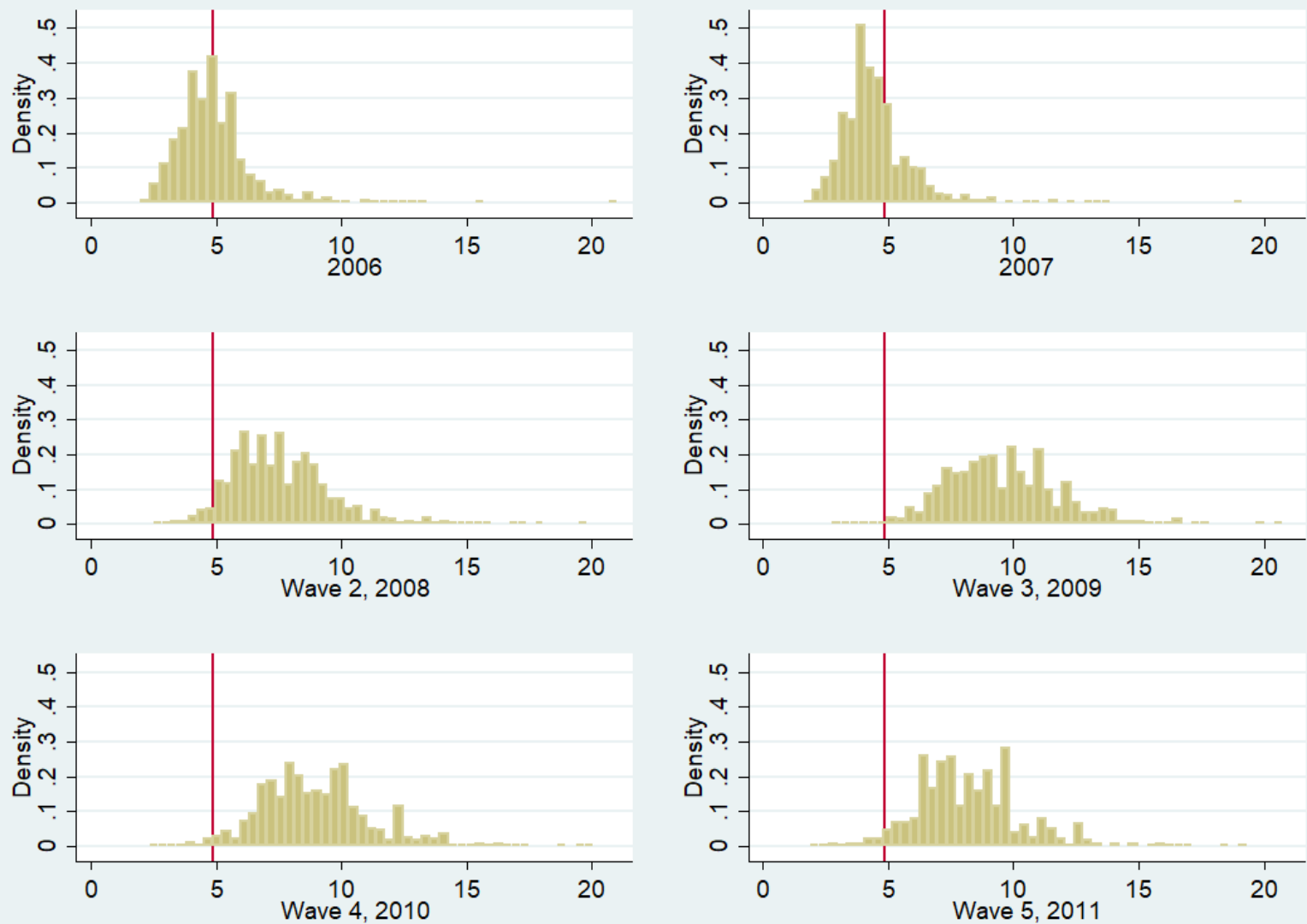

Note: Approximately 1,300 teachers in 2006, 2007, and wave 2; 1,100 in wave 3; 920 in wave 4; and 760 in wave 5. Provided calculations using sampling weights. 
Figure 4: Distribution of County Level Changes in the Unemployment Rate from School Year to School Year, Relative to 2006


Note: Approximately 1,300 teachers in 2006, 2007, and wave 2; 1,100 in wave 3; 920 in wave 4; and 760 in wave 5. Provided calculations using sampling weights. 


\section{Tables}

Table 1: Descriptive Statistics for Teacher, School, and Principal Characteristics - Overall and by Moving Status

\begin{tabular}{|c|c|c|c|c|}
\hline Variable & Mean & SD & $\begin{array}{c}\text { Mean } \\
\text { Stayers }\end{array}$ & $\begin{array}{c}\text { Mean } \\
\text { Movers }\end{array}$ \\
\hline \multicolumn{5}{|c|}{ Panel A: Teacher Characteristics } \\
\hline Item Non-Response & 0.02 & 0.04 & 0.02 & 0.02 \\
\hline Answerable Questions & 204.77 & 9.79 & 204.57 & 205.03 \\
\hline Female & 0.74 & & 0.72 & 0.77 \\
\hline Hispanic & 0.10 & & 0.11 & 0.09 \\
\hline White & 0.91 & & 0.92 & 0.89 \\
\hline Black & 0.08 & & 0.06 & 0.10 \\
\hline Alt. Cert. & 0.26 & & 0.20 & 0.33 \\
\hline$\geq$ Master's Degree & 0.16 & & 0.16 & 0.15 \\
\hline Had a Mentor & 0.89 & & 0.87 & 0.91 \\
\hline Pass Read. Praxis & 0.41 & & 0.41 & 0.40 \\
\hline Pass Math Praxis & 0.40 & & 0.41 & 0.39 \\
\hline Pass Writing Praxis & 0.49 & & 0.50 & 0.48 \\
\hline Max. Yrs. In School & 2.22 & 0.98 & 2.83 & 1.44 \\
\hline \multicolumn{5}{|c|}{ Panel B: School Characteristics } \\
\hline Proportion Black & 0.18 & 0.23 & 0.15 & 0.21 \\
\hline Proportion Hispanic & 0.21 & 0.28 & 0.19 & 0.22 \\
\hline Proportion FRL & 0.45 & 0.28 & 0.42 & 0.49 \\
\hline Enrollment & 821.57 & 590.01 & 844.33 & 792.08 \\
\hline Elementary School & 0.47 & & 0.47 & 0.47 \\
\hline Middle School & 0.18 & & 0.17 & 0.19 \\
\hline Combined School & 0.06 & & 0.06 & 0.06 \\
\hline Magnet School & 0.08 & & 0.07 & 0.08 \\
\hline Suburb & 0.29 & & 0.31 & 0.26 \\
\hline Town & 0.16 & & 0.19 & 0.13 \\
\hline Rural & 0.31 & & 0.29 & 0.34 \\
\hline
\end{tabular}


Table 1 continued

\begin{tabular}{lcccc}
\hline \multicolumn{1}{c}{ Variable } & Mean & SD & $\begin{array}{c}\text { Mean - } \\
\text { Movers }\end{array}$ & $\begin{array}{c}\text { Mean - } \\
\text { Stayers }\end{array}$ \\
\hline $\begin{array}{l}\text { Panel C: Principal Characteristics } \\
\text { Principal Factor }\end{array}$ & 0.13 & 0.95 & $\mathbf{0 . 2 0}$ & $\mathbf{0 . 0 4}$ \\
Female & 0.49 & & 0.51 & 0.47 \\
Black & 0.11 & & 0.09 & 0.13 \\
Hispanic & 0.08 & & 0.07 & 0.10 \\
Experience & 12.39 & 6.98 & 12.24 & 12.59 \\
Teaching Exp. & 0.23 & 1.42 & 0.13 & 0.35 \\
\hline
\end{tabular}

Note: Sample size approx. 1370. Bolded sample means are statistically significant at $\mathrm{p}<0.1$. Provided calculations using sampling weights. 
Table 2: Dynamics of Teacher Turnover, Average Marginal Effects

\begin{tabular}{|c|c|c|c|c|c|c|c|c|}
\hline & \multicolumn{2}{|c|}{ Year 2} & \multicolumn{2}{|c|}{ Year 3} & \multicolumn{2}{|c|}{ Year 4} & \multicolumn{2}{|c|}{ Year 5} \\
\hline & $(1)$ & (2) & (3) & $(4)$ & $(5)$ & $(6)$ & (7) & (8) \\
\hline Change Unemp. Rate & $\begin{array}{l}-0.020^{*} \\
(0.011)\end{array}$ & $\begin{array}{l}-0.017 \\
(0.012)\end{array}$ & $\begin{array}{l}-0.002 \\
(0.006)\end{array}$ & $\begin{array}{l}-0.001 \\
(0.006)\end{array}$ & $\begin{array}{l}0.012 * * \\
(0.006)\end{array}$ & $\begin{array}{l}0.015 * * \\
(0.006)\end{array}$ & $\begin{array}{l}-0.004 \\
(0.006)\end{array}$ & $\begin{array}{l}-0.004 \\
(0.005)\end{array}$ \\
\hline Item Non-Response & $\begin{array}{l}-0.042 * \\
(0.022)\end{array}$ & $\begin{array}{l}-0.046^{*} \\
(0.024)\end{array}$ & $\begin{array}{c}0.018^{* *} \\
(0.008)\end{array}$ & $\begin{array}{l}-0.002 \\
(0.019)\end{array}$ & $\begin{array}{l}-0.017 \\
(0.013)\end{array}$ & $\begin{array}{c}-0.135^{* *} \\
(0.054)\end{array}$ & $\begin{array}{c}0.007 \\
(0.011)\end{array}$ & $\begin{array}{c}0.004 \\
(0.024)\end{array}$ \\
\hline $\begin{array}{l}\text { Change Unemp. Rate } \\
* \text { Non-Response }\end{array}$ & & $\begin{array}{c}0.015 \\
(0.025)\end{array}$ & & $\begin{array}{c}0.008 \\
(0.007)\end{array}$ & & $\begin{array}{l}0.022 * * \\
(0.009)\end{array}$ & & $\begin{array}{l}-0.000 \\
(0.005)\end{array}$ \\
\hline Principal Quality & $\begin{array}{l}-0.021^{*} \\
(0.012)\end{array}$ & $\begin{array}{c}-0.028 * * \\
(0.013)\end{array}$ & $\begin{array}{c}0.002 \\
(0.010)\end{array}$ & $\begin{array}{l}-0.002 \\
(0.011)\end{array}$ & $\begin{array}{c}-0.036 * * * \\
(0.012)\end{array}$ & $\begin{array}{c}-0.038 * * * \\
(0.013)\end{array}$ & $\begin{array}{c}0.000 \\
(0.011)\end{array}$ & $\begin{array}{l}-0.006 \\
(0.011)\end{array}$ \\
\hline $\begin{array}{l}\text { Non-Response * } \\
\text { Principal Quality }\end{array}$ & & $\begin{array}{l}-0.029 \\
(0.023)\end{array}$ & & $\begin{array}{c}-0.032 * * \\
(0.015)\end{array}$ & & $\begin{array}{l}-0.004 \\
(0.023)\end{array}$ & & $\begin{array}{c}-0.038 * * \\
(0.019)\end{array}$ \\
\hline
\end{tabular}

Note: Sample size approx. 1,300 teachers in Year 2; 1,100 teachers in Year 3; 920 teachers in Year 4; and 760 in Year 5. Robust standard errors in parenthesis. $* * * \mathrm{p}<0.01, * * \mathrm{p}<0.05, * \mathrm{p}<0.1$. Controls for teacher's gender, ethnicity, if teacher is alternatively certified, if teacher has greater than or equal to a Master's degree, if the teacher has passed the Praxis exam in math, reading, or writing, ethnic composition of school, proportion of students eligible for free or reduced price lunch in school, school enrollment, school urbanicity, principal's gender, principal's ethnicity, principal's experience, and principal's experience teaching. 
Table 3: Dynamics of Probability of Staying, Average Marginal Effects

\begin{tabular}{|c|c|c|c|c|c|c|c|c|}
\hline & \multicolumn{2}{|c|}{ Year 2} & \multicolumn{2}{|c|}{ Year 3} & \multicolumn{2}{|c|}{ Year 4} & \multicolumn{2}{|c|}{ Year 5} \\
\hline & $(1)$ & (2) & (3) & (4) & $(5)$ & (6) & (7) & (8) \\
\hline Change Unemp. Rate & $\begin{array}{l}0.020 * \\
(0.011)\end{array}$ & $\begin{array}{c}0.017 \\
(0.011)\end{array}$ & $\begin{array}{c}0.002 \\
(0.006)\end{array}$ & $\begin{array}{c}0.002 \\
(0.006)\end{array}$ & $\begin{array}{c}-0.012 * * \\
(0.006)\end{array}$ & $\begin{array}{c}-0.015^{* *} \\
(0.006)\end{array}$ & $\begin{array}{c}0.004 \\
(0.006)\end{array}$ & $\begin{array}{c}0.006 \\
(0.005)\end{array}$ \\
\hline Item Non-Response & $\begin{array}{l}0.056^{* *} \\
(0.022)\end{array}$ & $\begin{array}{l}0.058 * * \\
(0.023)\end{array}$ & $\begin{array}{c}-0.018 * * \\
(0.008)\end{array}$ & $\begin{array}{c}0.003 \\
(0.019)\end{array}$ & $\begin{array}{c}0.019 \\
(0.014)\end{array}$ & $\begin{array}{c}0.142 * * * \\
(0.054)\end{array}$ & $\begin{array}{c}0.001 \\
(0.014)\end{array}$ & $\begin{array}{l}-0.012 \\
(0.026)\end{array}$ \\
\hline $\begin{array}{l}\text { Change Unemp. Rate } \\
* \text { Non-Response }\end{array}$ & & $\begin{array}{l}-0.014 \\
(0.024)\end{array}$ & & $\begin{array}{l}-0.007 \\
(0.007)\end{array}$ & & $\begin{array}{c}-0.022 * * \\
(0.009)\end{array}$ & & $\begin{array}{c}0.006 \\
(0.006)\end{array}$ \\
\hline Principal Quality & $\begin{array}{l}0.021 * \\
(0.012)\end{array}$ & $\begin{array}{l}0.025^{*} \\
(0.014)\end{array}$ & $\begin{array}{l}-0.006 \\
(0.011)\end{array}$ & $\begin{array}{l}-0.000 \\
(0.011)\end{array}$ & $\begin{array}{c}0.038 * * * \\
(0.012)\end{array}$ & $\begin{array}{l}0.041 * * * \\
(0.013)\end{array}$ & $\begin{array}{c}0.001 \\
(0.010)\end{array}$ & $\begin{array}{r}0.010 \\
(0.011)\end{array}$ \\
\hline $\begin{array}{l}\text { Non-Response * } \\
\text { Principal Quality }\end{array}$ & & $\begin{array}{c}0.022 \\
(0.025)\end{array}$ & & $\begin{array}{c}0.037 * * * \\
(0.014)\end{array}$ & & $\begin{array}{c}0.006 \\
(0.022)\end{array}$ & & $\begin{array}{l}0.041^{*} \\
(0.021)\end{array}$ \\
\hline
\end{tabular}

Note: Sample size approx. 1,300 teachers in Year 2; 1,100 teachers in Year 3; 920 teachers in Year 4; and 760 in Year 5. Robust standard errors in parenthesis. $* * * \mathrm{p}<0.01, * * \mathrm{p}<0.05, * \mathrm{p}<0.1$. Controls for teacher's gender, ethnicity, if teacher is alternatively certified, if teacher has greater than or equal to a Master's degree, if the teacher has passed the Praxis exam in math, reading, or writing, ethnic composition of school, proportion of students eligible for free or reduced price lunch in school, school enrollment, school urbanicity, principal's gender, principal's ethnicity, principal's experience, and principal's experience teaching. 
Table 4: Dynamics of Probability of Leaving, Average Marginal Effects

\begin{tabular}{|c|c|c|c|c|c|c|c|c|}
\hline & \multicolumn{2}{|c|}{ Year 2} & \multicolumn{2}{|c|}{ Year 3} & \multicolumn{2}{|c|}{ Year 4} & \multicolumn{2}{|c|}{ Year 5} \\
\hline & $(1)$ & (2) & (3) & (4) & (5) & (6) & (7) & (8) \\
\hline Change Unemp. Rate & $\begin{array}{l}-0.011 \\
(0.009)\end{array}$ & $\begin{array}{l}-0.007 \\
(0.010)\end{array}$ & $\begin{array}{l}-0.001 \\
(0.005)\end{array}$ & $\begin{array}{l}-0.001 \\
(0.005)\end{array}$ & $\begin{array}{l}0.011 * * \\
(0.005)\end{array}$ & $\begin{array}{l}0.013 * * * \\
(0.005)\end{array}$ & $\begin{array}{l}-0.001 \\
(0.004)\end{array}$ & $\begin{array}{l}-0.001 \\
(0.004)\end{array}$ \\
\hline Item Non-Response & $\begin{array}{l}-0.008 \\
(0.014)\end{array}$ & $\begin{array}{l}-0.010 \\
(0.017)\end{array}$ & $\begin{array}{l}0.014 * * \\
(0.007)\end{array}$ & $\begin{array}{l}-0.004 \\
(0.018)\end{array}$ & $\begin{array}{l}-0.012 \\
(0.012)\end{array}$ & $\begin{array}{c}-0.089 * * \\
(0.044)\end{array}$ & $\begin{array}{c}0.009 \\
(0.008)\end{array}$ & $\begin{array}{c}0.006 \\
(0.018)\end{array}$ \\
\hline $\begin{array}{l}\text { Change Unemp. Rate } \\
* \text { Non-Response }\end{array}$ & & $\begin{array}{c}0.019 \\
(0.021)\end{array}$ & & $\begin{array}{c}0.008 \\
(0.006)\end{array}$ & & $\begin{array}{c}0.014 * * \\
(0.007)\end{array}$ & & $\begin{array}{c}0.001 \\
(0.004)\end{array}$ \\
\hline Principal Quality & $\begin{array}{l}-0.011 \\
(0.010)\end{array}$ & $\begin{array}{l}-0.017 \\
(0.011)\end{array}$ & $\begin{array}{l}0.018^{*} \\
(0.010)\end{array}$ & $\begin{array}{c}0.016 \\
(0.010)\end{array}$ & $\begin{array}{c}-0.026^{* *} \\
(0.011)\end{array}$ & $\begin{array}{c}-0.027 * * \\
(0.012)\end{array}$ & $\begin{array}{l}-0.003 \\
(0.009)\end{array}$ & $\begin{array}{l}-0.005 \\
(0.009)\end{array}$ \\
\hline $\begin{array}{l}\text { Non-Response * } \\
\text { Principal Quality }\end{array}$ & & $\begin{array}{l}-0.027 \\
(0.018)\end{array}$ & & $\begin{array}{l}-0.018 \\
(0.012)\end{array}$ & & $\begin{array}{l}-0.002 \\
(0.020)\end{array}$ & & $\begin{array}{l}-0.014 \\
(0.016)\end{array}$ \\
\hline
\end{tabular}

Note: Sample size approx. 1,300 teachers in Year 2; 1,100 teachers in Year 3; 920 teachers in Year 4; and 760 in Year 5. Robust standard errors in parenthesis. $* * * \mathrm{p}<0.01, * * \mathrm{p}<0.05, * \mathrm{p}<0.1$. Controls for teacher's gender, ethnicity, if teacher is alternatively certified, if teacher has greater than or equal to a Master's degree, if the teacher has passed the Praxis exam in math, reading, or writing, ethnic composition of school, proportion of students eligible for free or reduced price lunch in school, school enrollment, school urbanicity, principal's gender, principal's ethnicity, principal's experience, and principal's experience teaching. 
Table 5: Dynamics of Probability of Changing, Average Marginal Effects

\begin{tabular}{|c|c|c|c|c|c|c|c|c|}
\hline & \multicolumn{2}{|c|}{ Year 2} & \multicolumn{2}{|c|}{ Year 3} & \multicolumn{2}{|c|}{ Year 4} & \multicolumn{2}{|c|}{ Year 5} \\
\hline & (1) & (2) & (3) & (4) & $(5)$ & (6) & (7) & (8) \\
\hline Change Unemp. Rate & $\begin{array}{l}-0.009 \\
(0.006)\end{array}$ & $\begin{array}{l}-0.010^{*} \\
(0.006)\end{array}$ & $\begin{array}{l}-0.001 \\
(0.003)\end{array}$ & $\begin{array}{l}-0.001 \\
(0.003)\end{array}$ & $\begin{array}{c}0.000 \\
(0.003)\end{array}$ & $\begin{array}{c}0.002 \\
(0.004)\end{array}$ & $\begin{array}{l}-0.003 \\
(0.004)\end{array}$ & $\begin{array}{l}-0.005 \\
(0.004)\end{array}$ \\
\hline Item Non-Response & $\begin{array}{c}-0.048^{* *} \\
(0.020)\end{array}$ & $\begin{array}{c}-0.048 * * \\
(0.020)\end{array}$ & $\begin{array}{c}0.005 \\
(0.005)\end{array}$ & $\begin{array}{c}0.001 \\
(0.009)\end{array}$ & $\begin{array}{l}-0.007 \\
(0.006)\end{array}$ & $\begin{array}{l}-0.053^{*} \\
(0.032)\end{array}$ & $\begin{array}{l}-0.010 \\
(0.013)\end{array}$ & $\begin{array}{c}0.005 \\
(0.020)\end{array}$ \\
\hline $\begin{array}{l}\text { Change Unemp. Rate } \\
* \text { Non-Response }\end{array}$ & & $\begin{array}{l}-0.005 \\
(0.012)\end{array}$ & & $\begin{array}{l}-0.001 \\
(0.003)\end{array}$ & & $\begin{array}{c}0.008 \\
(0.005)\end{array}$ & & $\begin{array}{l}-0.007 \\
(0.006)\end{array}$ \\
\hline Principal Quality & $\begin{array}{l}-0.010 \\
(0.007)\end{array}$ & $\begin{array}{l}-0.008 \\
(0.010)\end{array}$ & $\begin{array}{c}-0.012 * * \\
(0.005)\end{array}$ & $\begin{array}{c}-0.015 * * * \\
(0.006)\end{array}$ & $\begin{array}{l}-0.012 * \\
(0.007)\end{array}$ & $\begin{array}{c}-0.014 * * \\
(0.007)\end{array}$ & $\begin{array}{c}0.002 \\
(0.006)\end{array}$ & $\begin{array}{l}-0.005 \\
(0.007)\end{array}$ \\
\hline $\begin{array}{l}\text { Non-Response * } \\
\text { Principal Quality }\end{array}$ & & $\begin{array}{c}0.006 \\
(0.021)\end{array}$ & & $\begin{array}{c}-0.019 * * \\
(0.009)\end{array}$ & & $\begin{array}{l}-0.005 \\
(0.010)\end{array}$ & & $\begin{array}{r}-0.027 * * \\
(0.014)\end{array}$ \\
\hline
\end{tabular}

Note: Sample size approx. 1,300 teachers in Year 2; 1,100 teachers in Year 3; 920 teachers in Year 4; and 760 in Year 5. Robust standard errors in parenthesis. $* * * \mathrm{p}<0.01, * * \mathrm{p}<0.05, * \mathrm{p}<0.1$. Controls for teacher's gender, ethnicity, if teacher is alternatively certified, if teacher has greater than or equal to a Master's degree, if the teacher has passed the Praxis exam in math, reading, or writing, ethnic composition of school, proportion of students eligible for free or reduced price lunch in school, school enrollment, school urbanicity, principal's gender, principal's ethnicity, principal's experience, and principal's experience teaching. 


\section{Appendices}

Appendix 1: National Rate of Teacher Turnover

Appendix Table 1: Percentage of beginning public school teachers by teaching status from 200708 to $2011-12$

\begin{tabular}{cccc}
\hline School Year & Year of Career & Current Teachers & Former Teachers \\
\hline $2007-08$ & 1 & 100.0 & $\mathrm{n} / \mathrm{a}$ \\
$2008-09$ & 2 & 90.0 & 10.0 \\
$2009-10$ & 3 & 87.7 & 12.3 \\
$2010-11$ & 4 & 85.2 & 14.8 \\
$2011-12$ & 5 & 82.7 & 17.3 \\
\hline
\end{tabular}

Source: Gray \& Taie, 2015 
Appendix 2: Factor Loadings for Principal Quality Factor

Appendix Table 2: Factor Loadings for Principal's Quality Factor

\begin{tabular}{lc}
\hline Variable & Factor Loadings \\
\hline Principal Effectiveness Factor (Eigenvalue $=3.12$, Cronbach's alpha = 0.85) & \\
"The school administration's behavior toward the staff is supportive and & 0.83 \\
encouraging." & \\
"My principal enforces school rules for student conduct and backs me up when I & 0.82 \\
need it." & \\
"The principal knows what kind of school he or she wants and has communicated & 0.80 \\
it to the staff." & \\
"In this school, staff members are recognized for a job well done." & 0.78 \\
"I am generally satisfied with being a teacher at this school." & 0.72 \\
\hline
\end{tabular}

